\title{
'Malgudi' as the Nation-Space: A Critical Study Of R.K. Narayan's THE GUIDE (1958) AND ITS CINEMATIC ADAPTATION
}

\author{
SHYAMASRI MAJI \\ University of Burdwan \\ shyamasri.2010@gmail.com
}

Received: 09-09-2016

Accepted: 04-12-2016

\begin{abstract}
A study of the cultural ethos of a community initiates a dialogue between the people of that community and the place where the cultural ethos either originated or flourished. In R. K. Narayan's fiction, the town of Malgudi exudes such an in-depth connection with the characters living in and around it. Though Malgudi is an imaginary town, it has been regarded as "a real living presence" (Hariprasanna, 1994: 23) that "operates at two levels, the human and the topographical" (Hariprasanna, 1994: 23). This article aims to probe into this relationship between "the human and the topographical" by making a relative study of the presence of Malgudi (and its surrounding places) in The Guide (1958) and the absence of it in Guide (1965) - the cinematic adaptation of the novel. First, the article will analyse the spatial ${ }^{1}$ significance of 'Malgudi' in relation to the author's style of representing the Indian nation in the printed text. Secondly, it will critically examine the backdrop in the film text as a crucial deviation from the source text.
\end{abstract}

KEYWORDS: natio, local colour, cultural diversity, regionalism, postcolonial, mise-en-scene

RESUMEN "Malgudi" como nación-espacio: Un estudio crítico de El Guía (1965) de R.K Narayan, y su adaptación cinematográfica

Un estudio que se base en el ethos cultural de una comunidad inicia un diálogo entre la gente de esa comunidad y el lugar donde el ethos se originó, o bien donde floreció. En la ficción de R. K. Narayan, el pueblo de Malgudi rezuma una profunda conexión con los personajes que viven en él - o cerca de él. A pesar de que Malgudi es un pueblo imaginario, ha sido recibido como "una presencia viva y real" (Hariprassanna, 1994: 23) que "opera a dos niveles, el humano y el topográfico" (Hariprasanna, 1994: 23). Este artículo, al hacer una investigación relativa de la presencia de Maguldi (y sus alrededores), intenta probar esta relación entre "lo humano y lo topográfico" en la novela, y la ausencia de ella en la adaptación al cine. En primer lugar, el artículo analizará la importancia especial de "Malgudi" en relación con el estilo del autor a la hora de representar la nación india en un texto escrito. En segundo lugar, examinará criticamente el telón de fondo del texto de la película como una desviación crucial del texto original.

Palabras ClaVe: natio, color local, diversidad cultural, regionalismo, postcolonial, puesta en escena

\footnotetext{
${ }^{1}$ In general, the concept of 'place' refers chiefly to the objective projection of the items constituting a setting and that of 'space' suggests a social interface of cultural practices and experiences of the people in a particular place. Thus, spatiality of a landscape or any other form of location can be explored by mapping the cultural cartography of it.
} 
In the context of representation of the nation in postcolonial literature, Timothy Brennan observes that "the nation refers both to modern nation-state and to something more ancient and nebulous - the natio - a local community, domicile, family, condition of belonging” (Brennan, 1990: 45). In the repertoire of R.K.Narayan's fictional narratives, representation of the natio has found a cartographical outline in "Malgudi" - an imaginary town encompassing the author's perception of a local society as well as a nation in microcosm. Narayan could have written the nation in the microcosmic backdrop of any town or village that exists in reality but in that case Narayan's thoughts about the nation would have been restricted by the contours of reality. The real place exuding an impression of reality is bounded in the historical sense of the term by the limitations of time and space. The imaginary place seems to be more spatial than the real one in this respect. It allows the author to represent the reality perceived by him in a larger domain stretching far beyond the topographical and the historical boundaries. In the dialectics of place and space, Malgudi can be described as a nation-space "associated with freedom and mobility" (Huddard, 2005: 43). Malgudi "lives and grows and develops from novel to novel, from the early thirties to the early nineties" (Hariprasanna, 1994: 23) and in this way it "marks a movement of time which affects the geography of the place as well as the social, political and cultural contours of society, as Narayan's characters enact their own human drama" (Hariprasanna, 1994: 23).

The spatio-temporal cartography of Malgudi can be explored better when it is probed through the cultural code of 'local colour,' a term which refers to 'the detailed representation of the setting, dialect, customs, dress and ways of thinking and feeling which are distinctive of a particular region, such as Hardy's Wessex or Rudyard Kipling's India" (Abrams, 1999: 145). These aspects urge the readers to look at the fictional text as a narrative of regionalist discourse. By including the elements of regional culture in the setting of a narrative, the 'local colour' makes it an interactive domain for the characters belonging to a particular community or cultural group. Like Wessex in Thomas Hardy's fiction and the five towns ${ }^{2}$ in the novels of Arnold Bennet, Malgudi in the narratives of R.K. Narayan is a place replete with the regional attributes of a South Indian town. It is impossible to discuss the fictional art of R.K. Narayan without referring to Malgudi

\footnotetext{
${ }^{2}$ The five towns, which described life in the Potteries, were modeled on real towns. In the works of Bennet, these towns featured as Turnhill, Bursley, Hanbridge, Knype and Longshaw.
} 
because this imaginary location not only provides a locus standi to his fictional characters but also gives a local colour to his narrative. In The Guide, Malgudi seems to be a conduit connecting the rural with the urban, the colonial with the postcolonial and the natio with the modern nation-state.

In 1965, Narayan's novel The Guide (1958) was adapted into a film by a collaborative effort of Indian and American filmmakers. The Nobel laureate Pearl S. Buck wrote the screenplay of the English version of the movie Guide. The producer for both the English and the Hindi versions was Dev Anand, a renowned Bollywood actor. Although Guide became an epoch-making film in the history of Indian cinema, the deviations in the matter of representing the 'regional' stirred a lot of negative criticism. In this article, I try to analyse the discrepancies between the print text and the film text by comparing and contrasting the regional aspects of location in the two versions. Also, I would like to trace the factors responsible for the deviations in the film text.

In the register of cinema, 'location' refers to 'the properties or places (interior or exterior) used for filming away from the studio, set or (back) lot, often to increase the authenticity and realism of the film's appearance" (Dirks, 2016: www.filmsite.org). Filmed in Eastman colour, Guide undoubtedly made a "realistic and authentic" representation of location but the location and the local colour represented in the film are not the ones represented by Narayan in the book The Guide (1958). While the story in the book is set in Malgudi, the story in the film is set in Udaipur, a town in Rajasthan. We come to know from Narayan's autobiography My Days that he had protested against the dismissal of Malgudi from the screenplay but his outcries were ignored on the pretext that "[f]or wide-screen purposes, and that in colour, Jaipur offers an ideal background" (Narayan, 1996: 197). In his autobiography, he remarks, "By abolishing Malgudi, they had discarded my own values in milieu and human characteristics" (Narayan, 1996: 197). In his essay "Misguided Guide" he observes, "This was a shock. I had never visualized my story in that part of India .... My story takes place in South India, in Malgudi, an imaginary town known to thousands of my readers all over the world" (Narayan, 1988: 209). He further explains that "[i]t is South India in costume, tone and contents. Although the whole country is one, there are diversities, and one has to be faithful in delineating them" (Narayan, 1988: 210).

While the printed text reflects an initiative of underlining the diversity in the cultural narrative of the nation, the adapted version reveals the filmmakers' deliberate 
effort to show 'unity in diversity.' It is chiefly in the matter of dealing with the theme of 'unity in diversity' that the adapted text has proved unfaithful to the source text. In his article "Screening the Nation: Guide and the (Re)Production of India" Niladri R. Chatterjee comments that the film performs a "didactic function" (Chatterjee, 2012: 145) in narrating the nation on the silver screen. Several examples from the film, such as Raju's fluency in speaking various Indian languages and Rosie's finesse in performing the different Indian dance forms, show that the filmmakers' main concern was to represent "a culturally diverse but politically united India" (Chatterjee, 2012: 133). Chatterjee explains that in the year 1965, incidents such as the anti-Hindi agitations ${ }^{3}$ in South India against the establishment of Hindi as the national language and the outbreak of the second Indo-Pakistan War had threatened the "linguistic and territorial identity" of India (Chatterjee, 2012: 135). References to the different cities/states of the nation while depicting their culinary and aesthetic practices in the film serve as a strategy to highlight the nationalist ideal of unity in diversity. In this representation, however, 'diversity' has been overshadowed by the mission of projecting the idealistic 'unity.' The exotic backdrop of Rajasthan was certainly a befitting alternative to the Alpine sceneries of Kashmir, where most of the outdoor shootings of the Bombay film industry were done at that time (Chatterjee, 2012: 137). Since Indian writing in English was not as widely read at that time as it is today, many people were ignorant of Malgudi and Narayan's vision in the printed narrative, and this factor also contributed to the groundswell of applause for the film.

During a conversation with Tad Danielewski, the director of the English version of the picture, Narayan said, "You have to stick to my geography and sociology. Although it is a world of fiction there are certain inner veracities" (Narayan, 1988: 210). By "inner veracities," Narayan was referring to the cultural ethos of a particular community or social group which featured in almost all his literary works. These veracities characterised the cultural geography as well as the human geography of his imaginary place. In his

\footnotetext{
${ }^{3}$ During the early and the middle years of the 1960s, many South Indians opposed the central government's decision to make Hindi the sole official language of India. The proposal of making Hindi as the sole official language had been an issue of contestation since a decade before the Independence. Many non-Hindi speaking states, especially the ones in South India, could not accept the Official Languages Act in which the matter was proposed. In 1967, the Official Language Act was amended by the Congress government and both Hindi and English were declared as official languages of the nation.
} 
fictional mode, the place, the people and the cultural uniqueness of the two emerge as an overlapping terrain of socio-cultural identity.

Narayan wanted the filmmakers to locate Malgudi in any South Indian town that showed affinity to the geographical and cultural description of Malgudi in the book. The topography of Malgudi is based on real locations such as the banks of the river Kaveri, the Gopalaswami Hill and Nanjangud, a small town. Narayan tells us that he had taken the crew of filmmakers to these spots:

I showed them the river steps and a little shrine overshadowed by a banyan on the banks of Kaveri, which was the actual spot around which I wrote The Guide.... In the summer, when the river dried up, they could shoot the drought scenes with equal ease (Narayan, 1988: 208).

He also took the team to the base of the Gopalaswami Hill. At the summit of this hill there was an old bungalow which he called "Peak House" in his novel. Giving further information about the real places that helped to develop the spatial concept of Malgudi in The Guide, he says:

I took them to the tiny town of Nanjangud, with its shops selling sweets and toys and ribbons, and a pilgrim crowd bathing in the holy waters of the Kabini, which flowed through the town. The crowd was colourful and lively around the temple, and in a few weeks it would increase a hundredfold when people from the surrounding villages arrived to participate in the annual festival - the sort of crowd described in the last pages of my novel (Narayan, 1988: 208).

Narayan was hopeful that these locations could provide ready-made sets for the film. His hopes were deflated when the American director told him about their decision to exclude Malgudi as both 'location and culture' from the film.

Neither location nor culture can be explained separately without referring to each other. This is chiefly because culture is like a language and location gives a structure to this language. Although The Guide is written in English, the customs, the practices and the cultural mores of the people in Malgudi and Mangal (the village where Raju becomes a Swami) function as codes of the vernacular in the narrative. These cultural mores cannot be discussed without situating them at Malgudi. Simultaneously, the significance of Malgudi as a location in the book cannot be analysed without referring to the cultural traits of its inhabitants. The cultural distinctiveness of the Hindu community in South India is introduced at the very beginning of the novel. Velan, a villager, tells Raju that his daughter is married to his own sister's son (6). Marriage between cousins is prevalent among the Hindus in South India but such a custom is a taboo for the Hindus in North 
India. The film representing the location and culture of North India avoids any mention of such a marriage by the villager. Changes are made in every small detail to erase the local colour of Narayan's novel. In the film, the name of the villager is changed from Velan to Bhola and the name of the village is changed from Mangal to Rampuri. Both Bhola and Rampuri sound familiar to the North Indians to whom 'Velan' and 'Mangal' are typical South Indian names. 'Velan' is another name of Lord Murugan, the God of warfare in the Hindu mythology. Lord Murugan is widely worshipped in Tamil Nadu, Kerala, Sri Lanka, Malaysia and Philippines. In West Bengal, Odisha and Maharastra, he is popular by the name "Kartikeya." 'Bhola,' is another name of Lord Shiva, a major Hindu deity worshipped widely all over India. The word 'Rampuri,' literally meaning the abode of Lord Rama, an incarnation of Lord Vishnu, is representative of North Indian culture. In Hindi cinema, we often come across characters and places named after Lord Rama. Thus, the cultural codes in the source text were uprooted from the South Indian ethos and were planted in the North Indian locale in order to represent a typical "pan-Indian" backdrop of the contemporary Hindi cinema. A significant deviation is also seen in the representation of Rosie's art-her dance. In the book, Rosie is a trained Bharatnatyam dancer. Bharatnatyam is a classical form of Indian dance with roots in Tamil culture. In ancient times, this form of dance was called dasiyattam as it was performed by the devadasis (maid servants of God) in the temples of South India (Soneji, 2006, 2013, http://www.thecanadianencyclopedia.ca/en/article/indian-classical-dance/). In the book it has been clearly mentioned that Rosie hailed from the matrilinear family of temple dancers whom people viewed as "public women" (Narayan, 1958: 84). She explains to Raju that the women of her class are not "considered respectable" in society (Narayan, 1958: 84). In spite of having a university degree in Economics, she could not get rid of the social stigma that shrouded her 'class identity' (Narayan, 1958: 85). She had married Marco, an archeologist, in order to get the respectable identity of a 'wife' in society. So, marriage to her was just a truce to upgrade her social status.

In the book, Narayan makes it clear that Rosie's shows and performances are limited to the territorial bounds of South India. In Chapter 9 of the book Raju says, "Our engagements took us to all corners of South India, with Cape Comorin at one end and the border of Bombay at the other, and from coast to coast" (Narayan, 1958: 191). In the film, Waheeda Rahman playing the role of Rosie is not represented as a Bharatnatyam dancer. The dance shows in the film are represented as typical Bollywood performances with a 
troop of dancers accompanying Rosie during her stage shows. Her changing costumes are representatives of the different Indian dance forms such as Kathak, Bharatnatyam, Manipuri and folk tradition. The dance performances are choreographed on the popular soundtracks of the film. Another point of deviation is that the dance shows in the film take place both in India and abroad. About the deviation in Rosie's professional status, Narayan commented:

I did not expect the heroine, the dancer, to be more than a local star, but the film heroine became a national figure whose engagements caused her to travel up and down hundreds of miles each day in a Boeing 707, autographing, posing for photographers, emerging from five-star hotels and palatial neon-lit theatres (Narayan 1996: 197).

It is possible that Narayan represented Rosie as local star in order to justify her effort to re-form the status of Bharatnatyam dance and the Bharatnatyam dancer in the South Indian society. Perhaps he wanted his readers to re-consider their existing views on devadasis and their dance form. There was a need for this kind of re-consideration because "[d]uring the colonial period, the somewhat ambiguous (i.e. non-married) social status of devadasis [had] caused the art form to fall into disrepute in the eyes of both the Victorian ruling elite and the emerging Indian middle class" (Soneji, 2006, 2013, www.thecanadianencyclopedia.ca/en/article/indian-classical-dance/). It can be said that by emphasising the local elements he had tried to counter and contest the onedimensional portrayal of the Indian culture in the mainstream films of Hindi cinema, which by then had already established itself as the most popular form of public culture in India. The deviation in the film text thwarted the author's effort of foregrounding the 'local' in the global context of cultural representation.

Other deviations in the film text, such as the dress code and food habits of the characters, also reveal the politics of representing the different regional cultures within a culturally diverse nation space. As has been discussed earlier with reference to Niladri R. Chatterjee's article, these deviations represent an effort to suppress a regional group that had raised its voice against the Government's proposal of making 'Hindi,' (the language spoken by the majority population in North India) the official language of the nation. Thus, the political implications of the deviations compel a viewer to look at these as deliberate manipulations of the cultural codes presented in the printed text.

These deviations not only add to the list of cultural differences between the film text and printed text but also encourage one to look at dress code and food habits of a 
community in terms of the Saussurian concepts of 'langue' and parole. ${ }^{4}$ In The Guide, the particular set of garments worn by the major characters and the particular menu of food items mentioned by the novelist function as parole in the structural analysis of the cultural language of South India. In the book, Raju wears dhoti and jibba. In Karnataka and Tamil Nadu, it is the typical dress code for men. In the film, Dev Anand playing the role of Raju is never seen in dhoti and jibba. He dresses in Western clothes that were in fashion those days and walks in his usual style with the folded coat slung over his shoulder. It is quite difficult to identify him with Narayan's Raju in the matters of appearance and outlook.

As far as the representation of food habits is concerned, Narayan mentions in his book the names of popular South Indian dishes such as idli and dosa. In the first chapter of the book, Narayan not only describes Raju's dislike of fruit for breakfast, but also mentions his preference to begin the day with coffee and idli (Narayan, 1958 :18). In the film, we can see Raju swallowing chapatti and curry, which are the staple food items in North India. The filmmaker deliberately features these food items to represent the local colour of North India in the film. People in South India prefer coffee to tea. In his book, Narayan emphasises the preference of the people in South India by giving an elaborate description of the ceremonious advertisement and campaigning of the Tea Board at Mangal:

The Tea Propaganda Board opened a big tea stall, and its posters, green tea plantations along the slopes of blue mountains, were pasted all around the temple wall. (People drank too much coffee and too little tea in these parts.) It had put up a tea-bar and served free tea in porcelain cups all day (Narayan, 1958: 239).

When beverages are served in the film, it is assured that the item is tea instead of coffee because people in North India prefer tea to coffee. The sole purpose of making such deviations in the film was to shift the location and culture of the narrative from South India to North India.

In the film, an enormous length of screen time is devoted to images of the land, the road, and the towns of Rajasthan. This manner of representing the locale or the physical backdrop in this film contributes to the structure of the narrative because it depicts the story of a tourist guide. But this does not provide a reasonable answer for the shift of the

\footnotetext{
${ }^{4}$ In his book The Language of Fashion, Roland Barthes discusses the relationship between the system of language and clothes representing one of the cultural codes of a community. Analysing the views of Trubetskoy, who suggested the application of Saussurian concepts of langue and parole to clothing, Barthes tells us that "like langue, clothing would be an institutional system...from which individual wearers would draw their apparel" (Barthes, 2004: 25). The comparison can be applied to food as well because food items like garments function as a cultural code in society.
} 
location from South India to North India. A quest for the answer brings us face to face with the issue of cross-cultural encounter. Guide was, after all, a collaborative effort of a team of Indian and American filmmakers for representing primarily an Indian story with a completely Indian star cast to the audience of the West. They wanted to represent on screen the 'spectacular' India described in travelogues and history books. The featuring of the historical architecture, culture and ethnoscape of Udaipur, Chittor and Jaipur were ideal for this purpose. During the the popular soundtrack "aaj phir jeeney ki tamanna hai" ("I wish to live once again"), Raju, Rosie and the other tourists ride on the backs of camels. On their way to Chittor, a tourist spot in Rajasthan, they come across a few women dressed in ghagra-choli with colourful clay pots on their heads. The landscape foregrounds a picture of the agricultural India that lives in the heat and dust of the villages. In the English version of the movie, the director also shows a fight between two tigers for representing symbolically the rivalry between Raju and Marco. These things represent the ethnoscape of India as it is stereotypically represented in the occidental discourses of travel literature. Besides, the screening of the royal palaces and forts through different kinds of shots/reverse shots enhance the historical significance of the location in a spectacular way. Location in the film functions technically and does nothing more than fulfil the filmmaker's purpose of representing the mise-en-scene as a spectacle.

Unlike the film, the book makes use of location for dealing with some serious issues. In The Guide, Narayan uses location as a trope for historicising the transition of a nation-cum-society from tradition to modernity. C.D. Narasimhaiah tells us that the setting of the novel not only shows the transition of the agricultural economy but also "serve[s] as an authentic background for the different phases the characters go through" (Narasimhaiah, 2012: 126). Thus, according to Narasimhaiah, the change in the spatiotemporal setting complements the transition of Raju's character from "the state of innocence to the state of experience" (Narasimhaiah, 2012: 126). Before the arrival of the railways, Malgudi was a small town where people followed a rural lifestyle. Raju's father had a small shop where the village folks gathered and discussed issues related to agriculture and old litigations. At home, they domesticated a pair of buffaloes for milk and dung. In the morning, Raju washed himself and smeared holy ash on his forehead. Then he recited the sacred rites and memorised the Tamil alphabet and numbers in front of his father. Railways symbolised the intervention of colonialism in that rural place. The impact of the colonial intervention in the Eden-like Malgudi was good as well as bad. The 
railways connected Malgudi with the world. As a result of this connection the rural location began to improvise the features of modernity and urban setting - hotels, taxis, photo laboratory, cinema hall etc. The uni-dimensional rural setting of Malgudi becomes multi-dimensional. Raju describes this transformation as follows:

Malgudi, I said, had many things to offer, historically, scenically, from the point of view of modern developments... or if one came as a pilgrim I could take him to a dozen temples all over the district within a radius of fifty miles; I could find holy waters for him to bathe in all along the course of the Sarayu, starting of course, with its source on Mempi peaks (Narayan, 1958: 62).

Railways also infused the perversions of modern urban life in the rural society of Malgudi. In his childhood, Raju picked up abusive words from the men who laid down the railway tracks. As a guide, he often manipulated facts to make them more interesting to the tourists. Later, he was arrested on the charge of forgery. After his release from jail, he goes to a village called Mangal. Here, his character undergoes transformation. Like Malgudi, Mangal is also an imaginary location representing an underdeveloped nation of the Third World. There are so many problems in this village-cum-underdeveloped nation-lack of school, post office, medical facilities etc. These problems threaten the progress of a nation even after its independence from the yoke of foreign rule. Both Malgudi and Mangal reify Narayan's vision of the nation. This vision sometimes is ironic. On the one hand, this is a place of pilgrimage where faith can transform a picaro into a Mahatma (the great soul); on the other hand, this is the place of exhibition and sales. Both hawkers and government officials throng the place to exhibit their own commodities and ideas:

The khaki-clad health inspector sprayed every inch of space with DDT and, with a needle in his hand, coaxed people to inoculate themselves against cholera, malaria.... When he had done with health, he showed a few Government of India films about dams, river valleys, and various projects, with ministers delivering speeches. Far off, outside the periphery, a man had opened a gambling booth with a dart-board on a pole, and he had also erected a crude merry-go-round, which whined all day. Pedlars of various kinds were also threading in and out, selling balloons, reed whistles, and sweets (Narayan, 1958: 239-240).

Juxtaposition of the campaigning of the Government officials with the activities of the pedlars gives us an opportunity to look at Mangal as a postmodernist text in which distinctions between the high and the low are abolished. The juxtaposition strengthens the irony in Narayan's vision of the nation. At a place where there are no dams, bridges or 
health centers, the exhibition of these in documentary films is nothing other than the Government's policy for securing votes by disseminating information of national developments. In this way, Narayan looks at the issue of nation from various perspectives, and the regional setting in the book becomes a "space that expands and contracts in time assuming the dimension of a Bakhtinian chronotope" (a complex matrix of time and space)" (Bhattacharya, 2004: 28).

In the film, neither Raju's childhood nor the railways are brought into focus. Following the popular cult of hero-worship in commercial cinema, the character of Raju the Guide has been exalted to such an extent that this exaltation has overshadowed the issues of nation, government and condition of people in the film. Although the narrative of the film is adapted from Narayan's novel, Narayan's perspectives on nation have been brushed aside by the filmmakers. It seems that the latter had been sly enough to use the name of a Sahitya Akademi Award winning author as a ploy to coat their melodramatic screenplay with an aesthetic tint. Seen from this angle, the author of the printed text is just another commodity in the consumerist platform of commercial film-making. The value of his fame and perspectives can be auctioned and appropriated according to the terms and conditions of the media market.

James Martin explains that "[s]patial location is important, not only in generating shared experiences and customs that form identities but also in providing a 'position' from which resistance can be made against power, inequality and...oppression" (Martin, 2005: 98). The exclusion of the regional location and the milieu from the Guide not only results in the exclusion of Narayan's vision of the nation from the film but also erases his protocols of resistances as a postcolonial author. By highlighting the exotic and the orient in the mise-en-scene, the filmmakers have satisfied their commercial interests. Simultaneously, by erasing the evolving trend of representing nation in Indian writing in English, they have depleted the aesthetic as well as the ethical value of what has been referred to as celebration of the "glocal" in recent postcolonial criticism. It is still to be explored whether any member of the Indian crew objected to this kind of commercialisation. However, the manipulation of the socio-cultural identities of the characters on the silver screen reveals how cultural imperialism operated during the making of this film. This kind of manipulation reveals how far the oppressive traits of neo-colonial discourse controlled the thoughts and the actions of the so-called postcolonial subjects. 
A general survey of the popular films of Bollywood shows that the regional cultures and the characters are mostly presented as butts of ridicule in mainstream Hindi cinema. It is possible that this kind of mindset of the Indian members of the production team was a reason for the exclusion of the South Indian milieu from the film. In the cinematic translation of R.K. Narayan's novel The Guide, the biggest loss is the erasure of Narayan's socio-cultural outlook of the nation and the nationals. In a multiethnic nation like India, a regional backdrop helps an author to represent the socio-economic condition of the nationals in a unique manner. Can we think of visualising Satyajit Ray's film Pather Pachali (1955) adapted from the fiction of Bibhutibhushan Bandopadhyay in any other milieu than the one portayed in the book? Study of the locale is often treated as a trivial aspect in film appreciation. It becomes a significant aspect of study while making a critical analysis of the film Guide because it pinpoints how the South Indian community and culture are made "the Other" by both Indians and foreigners. The deviation in the representation of the locale in the film, whether it has been made for commercial purposes or for cultural animosities, projects the risk of incommensurable loss in the process of adapting a printed text into a film text.

Even fifty years after the adaptation, the source text and the cinematic version raise critical concerns. The issues of cultural diversity that had threatened the nation's unity on the eve of Indian Independence, have been confounding and problematising the discourse of national integrity to this day. With the establishment of four new states ${ }^{5}$ in the republic of India it has become clear that the diverse cultures need recognition through proper representation of the cultural distinctiveness of the different groups. From this perspective, it can be said that 'Malgudi' had initiated the debate of inadequate representation of a particular section of the Indian population in Bollywood films. The film version doting on the idealistic tenets of patriotism has missed out the post-colonial reality inscribed in Narayan's Malgudi. Keeping in mind the spatial significance of this imaginary place, we can hope to see another version in which the story of Raju the Guide will be set in Malgudi.

\footnotetext{
${ }^{5}$ The four new states in the republic of India are Chhattisgarh (2000), Uttarakhand (2000), Jharkhand (2000) and Telangana (2014). At present, there are 29 states and 7 union territories in India.
} 


\section{WORKS CITED}

ABRAMS, M.H (1999). A Glossary of Literary Terms. Heinle: Thomson.

ANAND, VIJAY (1965) dir. Guide. Performance. Dev Anand, Waheeda Rahman. Film.

BARTHES, ROLAND (2004). The Language of Fashion. London: Bloomsbury. [2013]

BHATTACHARYA, NANDINI (2004). R.K. Narayan's The Guide: New Critical Perspectives. Delhi: Worldview.

BRENNAN, TIMOTHY (1990). “The National Longing for Form.” In: Homi K. Bhabha (ed.) Nation and Narration. (ed.) London: Routledge: 44-70.

CHATTERJEE, NILADRI, A. (2012). "Screening the Nation: Guide and the (Re)Production of India." In: Raymond-Jean Frontain and Basudeb Chakraborti (eds.) A Talent for the Particular: Critical Essays on R.K. Narayan. Delhi: Worldview: 133-146.

DIRKS, TIM (2016). "Film Terms Glossary." Filmsite. <www.filmsite.org/filmterms 11. html> accessed 5 Sept. 2016.

HARIPRASANNA, A. (1994). The World of Malgudi: A Study of R.K. Narayan's Novels. New Delhi: Prestige Books. [Rpt.1998]

HUDDARD, PHIL (2005). "Space/Place." In: David Atkinson et al. (eds.) Cultural Geography: A Critical Dictionary of Key Concepts. Jaipur: Rawat Publications: 41-48.

MARTIN, JAMES (2005). "Identity." In: David Atkinson et al. (eds.) Cultural Geography: A Critical Dictionary of Key Concepts. Jaipur: Rawat Publications: 97-102.

MCLEOD, JOHN (2011). Beginning Postcolonialism. New Delhi: Viva Books.

NARASIMHAIAH, C.D.(2012). “R.K. Narayan's The Guide.” In: C.N. Srinath (ed.) R.K. Narayan: An Anthology of Recent Criticism. New Delhi: Pencraft International: 126-147.

NARAYAN, R.K.(1958). The Guide. Chennai: India Thought Publications. [59 ${ }^{\text {th }}$ Rpt. 2005]

---(1988).“Misguided Guide.” Writer's Nightmare. New Delhi: Penguin Books India: 206217.

---(1996). My Days. New Delhi: Viking. 
SONEJI, DEVESH (2006). “Indian Classical Dance.” Historica Canada. 15 Dec. 2013. http://www.thecanadianencyclopedia.ca/en/article/indian-classical-dance/ accessed 5 Sept. 2016.

SHYAMASRI MAJI teaches English at NSHM Knowledge Campus-Durgapur. She completed her MA (2007) and M.Phil (2009) in English from the University of Burdwan (India) where she is, at present, pursuing a $\mathrm{Ph} . \mathrm{D}$ on the memoirs and the novels of select Anglo-Indian writers. Areas of her research interest include Diasporic Studies and Postcolonial literature. 